\title{
Bronchogenic Cyst
} in Posterior Mediastinum with Butterfly Vertebra: A Case Report 접형척추를 동반한 후종격동 기관지낭: 증례 보고

\author{
Myeongjong Kim, MD ${ }^{1}$ iD, Hyun Jin Park, $\mathrm{MD}^{1^{*}}$ (D), \\ Jeong Min $\mathrm{Ko}, \mathrm{MD}^{1} \mathbb{D}$, Jinyoung Yoo, $\mathrm{MD}^{2}$ (D) \\ Departments of ${ }^{1}$ Radiology, ${ }^{2}$ Pathology, St. Vincent's Hospital, College of Medicine, \\ The Catholic University of Korea, Seoul, Korea
}

Most mediastinal cystic masses result from abnormal development of the embryo. Common developmental cysts in the posterior mediastinum are bronchogenic, neurenteric, and esophageal duplication cysts. These cystic masses appear identical on CT, but a cystic lesion adjacent to the esophagus is usually an esophageal duplication cyst, and a cyst associated with vertebral anomalies indicates a presumptive diagnosis of a neurenteric cyst. Herein, we present the case of a 27-year-old man with a bronchogenic cyst in the posterior mediastinum with a butterfly vertebra.

Index terms Bronchogenic Cyst; Neurenteric Cyst; Spinal Dysraphism

\section{INTRODUCTION}

The simultaneous presentation of a mediastinal cyst with an accompanying vertebral abnormality is the hallmark of a neurenteric cyst (1). Neurenteric cysts arise during early embryogenesis when the foregut and notochord are in close proximity. Adhesion between the two may cause the foregut to invaginate and pinch off, forming an enteric cyst that may demonstrate intraspinal extension. Therefore, the coexistence of vertebral anomalies is strongly suggestive of neurenteric cysts. Neurenteric cysts are typically located in the posterior mediastinum (2). The patient in our case had a posterior mediastinal cystic mass and a butterfly vertebra, whose later pathological examination proved to be a bronchogenic cyst.
Received February 19, 2019

Revised April 25, 2019

Accepted April 25, 2019

*Corresponding author Hyun Jin Park, MD Department of Radiology, St. Vincent's Hospital, College of Medicine, The Catholic University of Korea, 222 Banpo-daero, Seocho-gu, Seoul 06591, Korea.

Tel 82-31-249-8490 Fax 82-31-249-7479

E-mail radiodoc@catholic.ac.kr

This is an Open Access article distributed under the terms of the Creative Commons Attribution Non-Commercial License (https://creativecommons.org/ licenses/by-nc/4.0) which permits unrestricted non-commercial use, distribution, and reproduction in any medium, provided the original work is properly cited.

\section{ORCID iDs}

Myeongjong Kim (D) https://

orcid.org/0000-0001-7215-527X

Hyun Jin Park (D)

https://

orcid.org/0000-0003-0130-0702 Jeong Min Ko (iD) https:// orcid.org/0000-0002-8996-5786 Jinyoung Yoo (D) https://

orcid.org/0000-0002-5053-1489 


\section{CASE REPORT}

A 27-year-old man presented with chest X-ray abnormalities. He had no clinical symptoms and no medical history. Physical examination and routine laboratory test results were normal. Chest radiography showed an approximately $5 \mathrm{~cm}$, sharply-defined round mass in the left paravertebral area, obscuring left paraaortic interface, and a paravertebral stipe. These findings indicated that the mass was located in the posterior mediastinum (Fig. 1A). On CT scan, the mass was a well-circumscribed, hypodense cystic lesion without contrast enhancement (28 Hounsfield unit) in the posterior mediastinum, near the descending thoracic aorta and 11th thoracic vertebra. The cyst had no definable wall or calcification (Fig. 1B). Coronal reformatted CT images revealed that the thoracolumbar curvature was "S"-shaped and the 6th thoracic vertebral body had a sagittal cleft through the body with the appearance of a butterfly. There was no communication between the cystic mass and the cleft (Fig. 1C). Our preoperative diagnosis was a neurenteric cyst associated with a butterfly vertebra. The patient underwent video-assisted thoracoscopic surgery for excision of the mass. Examination of the pathologic specimen revealed that the cyst wall was lined by ciliated pseudostratified columnar epithelium, including mature cartilage and submucosal glands (Fig. 1D).

\section{DISCUSSION}

Foregut cysts probably result from aberrant development of the primitive foregut and are classified into three types: bronchogenic, esophageal duplication, and neurenteric cysts. Bronchogenic cysts are thought to arise from the abnormal budding of the ventral foregut, which forms the tracheobronchial tree. Histologic findings of respiratory epithelium provide the definitive diagnosis of a bronchogenic cyst. Esophageal duplication cysts are thought to arise from the dorsal foregut, destined to be the alimentary tract. Histologic findings of a submucosal or muscular layer of the gastrointestinal tract provide the definitive diagnosis of an esophageal duplication cyst $(3,4)$. Neurenteric cysts result from the failure of the alimentary tract to separate from the primitive neural crest, leaving a persistent communication between the foregut and the spinal cord (1). Histologically, both neural elements and gastrointestinal epithelium are typically seen (3).

Each type of foregut cyst has similar CT findings, with characteristic locations in the chest. On CT, all three types of foregut cysts usually appear as solitary well-circumscribed round or oval cystic masses with fluid attenuation $(3,5)$. Bronchogenic cysts are most frequently found in the middle mediastinum, near the carina, and less frequently in any part of mediastinum or chest $(6,7)$. Esophageal duplication cysts are usually located along the esophagus in the lower posterior mediastinum. Most neurenteric cysts are located in the posterior mediastinum $(6,8)$. In cases where these cysts share anatomic locations, differentiation by CT becomes very difficult (6).

Foregut cysts may be accompanied by other congenital anomalies. Bronchogenic cysts are occasionally associated with congenital pulmonary malformations and 12\% of patients with esophageal duplication cysts also have malformations of the gastrointestinal tract (1). Half of all neurenteric cysts are associated with cervical and upper thoracic vertebral anomalies, 
such as hemivertebrae, butterfly vertebrae, anterior spina bifida, and scoliosis. Intravertebral extension of the foregut can disrupt vertebral body development and induce a sagittal cleft defect. Because of the cephalic growth of the notochord and caudal growth of the foregut, any associated vertebral defects are typically superior to the mediastinal cyst (4). CT can demonstrate a connection of the cyst to the spinal defect. However, they can also manifest as an isolated mediastinal cyst with no spinal connection or they may have a fibrous tract to the attached spine. Therefore, the combination of a posterior mediastinal cyst with vertebral defect

Fig. 1. Bronchogenic cyst in the posterior mediastinum with butterfly vertebra in a 27-year-old man. A. Chest X-ray image shows a well-defined mass (M) in the left paravertebral area, obscuring the left paraaortic interface (arrows) and paravertebral stripe (arrowheads). These findings suggest that the mass is located in the posterior mediastinum. The curvature of the thoracolumbar spines is S-shaped, representing mild scoliosis.

B. Contrast-enhanced axial CT image shows a cystic mass with homogeneous fluid attenuation in the left paravertebral area, at the 11th thoracic vertebral level. The cyst wall has no definite boundary or calcifications. C. Coronal CT image shows that the 6th thoracic vertebral body has a sagittal cleft with a butterfly appearance (arrows). The cystic mass is seen partly caudal to the vertebral defect. Scoliosis is also seen.

D. Micrograph shows ciliated pseudostratified columnar epithelium, smooth muscle fibers, and mature cartilage (hematoxylin and eosin stain, $\times 100$ ).
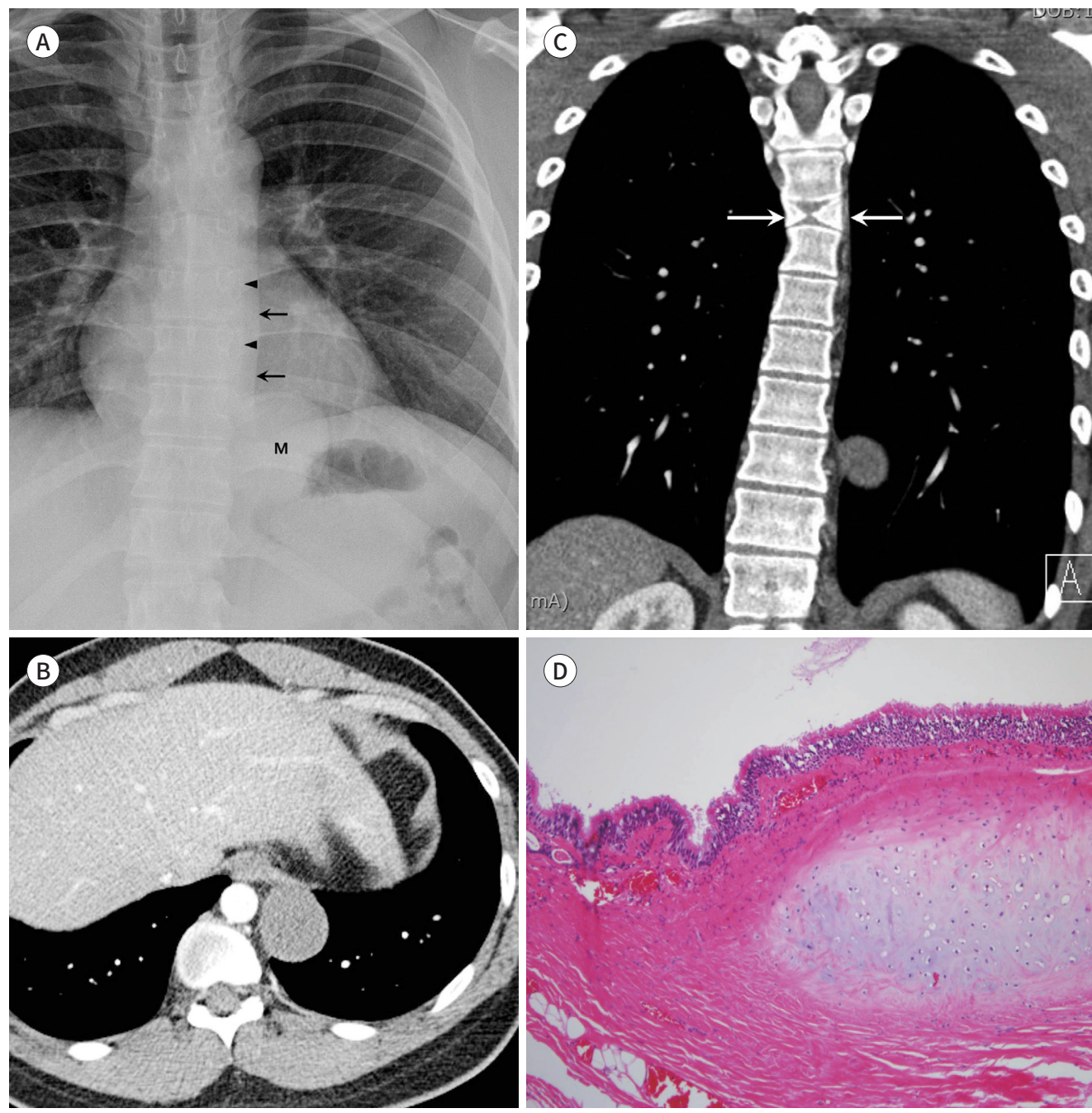
anomalies is virtually diagnostic of a neurenteric cyst, with or without a spinal connection (1).

In our case, a typical mediastinal cyst was located in the posterior mediastinum, ventral to the 11th thoracic vertebral body. There were two vertebral anomalies, a butterfly vertebra of the 6 th thoracic vertebral body and scoliosis. The vertebral anomaly was superior to the cyst. All these findings strongly identified the cyst as a neurenteric cyst. However, examination of the pathologic specimen revealed respiratory epithelium lining in the cyst and identified it as a bronchogenic cyst. We could not find any case of a bronchogenic cyst associated with the presence of a butterfly vertebra and scoliosis using Google and Pubmed. A bronchogenic cyst can be present in a patient with vertebral anomalies. If the communication between the cyst and the vertebral defect is not clearly identified, a bronchogenic cyst, as well as a neurenteric cyst, should be included in the differential diagnosis.

\section{Author Contributions}

Conceptualization, P.H.J., K.J.M.; data curation, K.M., K.J.M., P.H.J.; formal analysis, K.M., P.H.J.; investigation, K.M.; project administration, P.H.J.; resources, K.J.M., Y.J.; supervision, P.H.J.; visualization, K.M., K.J.M., Y.J.; writing-original draft, K.M.; and writing-review \& editing, P.H.J.

\section{Conflicts of Interest}

The authors have no potential conflicts of interest to disclose.

\section{REFERENCES}

1. Vargas D, Suby-Long T, Restrepo CS. Cystic lesions of the mediastinum. Semin Ultrasound CT MR 2016;37: 212-222

2. Lee SH, Dante SJ, Simeone FA, Curtis MT. Thoracic neurenteric cyst in an adult: case report. Neurosurgery 1999;45:1239-1242; disscussion 1242-1243

3. Ranganath SH, Lee EY, Restrepo R, Eisenberg RL. Mediastinal masses in children. AJR Am J Roentgenol 2012;198:W197-W216

4. Strollo DC, Rosado-de-Christenson ML, Jett JR. Primary mediastinal tumors: part II. Tumors of the middle and posterior mediastinum. Chest 1997;112:1344-1357

5. Yoon JH, Lee KN, Kang EJ, Kim MS, Choi PJ, Roh MS. Bronchogenic cyst in an intradiaphragmatic location: a case report. J Korean Soc Radiol 2018;79:227-232

6. Kawashima A, Fishman EK, Kuhlman JE, Nixon MS. CT of posterior mediastinal masses. Radiographics 1991;11:1045-1067

7. Vilela TT, Daher RT, Nóbrega MD, Ximenes Filho CA, Montandon C, Montandon Júnior ME. Congenital mediastinal cysts: imaging findings. Radiologia Brasileira 2009;42:57-62

8. Occhipinti M, Heidinger BH, Franquet E, Eisenberg RL, Bankier AA. Imaging the posterior mediastinum: a multimodality approach. Diagn Interv Radiol 2015;21:293-306 
접형척추를 동반한 후종격동 기관지낭: 증례 보고

김명종 ${ }^{1} \cdot{\text { 박현진 } 1^{*} \cdot \text { 고정민 }}^{1} \cdot$ 유진영2

대부분의 종격동낭은 태아의 비정상적인 발달에서 유래한다. 후종격동의 흔한 선천성낭에는 기관지낭, 신경장낭 및 식도중복낭이 있다. 이들은 CT에서 비슷하게 보여 감별진단이 어렵다. 하지만, 척추기형의 동반은 신경장낭에서만 보이는 특징적인 소견으로, 이런한 동반기형이 있 을 경우 수술 전 진단이 가능한 것으로 알려져 있다. 저자들은 척추의 접형기형을 가진 27세 남 자 환자에서 후종격동 기관지낭이 진단된 드문 증례를 경험하였기에 이를 보고하고자 한다.

가톨릭대학교 의과대학 성빈센트병원 ${ }^{1}$ 영상의학과, ${ }^{2}$ 병리과 